\title{
Oral health profile of education and health professionals attending handicapped children ${ }^{\dagger}$
}

\section{Perfil em saúde bucal de profissionais de educação e saúde que atendem crianças portadoras de necessidades especiais}

\author{
Luciana Pomarico* \\ Ivete Pomarico Ribeiro de Souza** \\ Luiz Fernando Rangel Tura***
}

\begin{abstract}
The purpose of this study was to evaluate the knowledge and attitudes toward oral health of education and health professionals working in a children care program for handicapped children from 0 to 6 years of age, run by a public municipal institution in Rio de Janeiro. Using a printed questionnaire, 67 professionals (teachers, attendants and health professionals) were interviewed. The results were compared to the children's oral hygiene habits, by directly observing their daily nursery routine. Although $97.0 \%$ said that oral health could play a part in general health, only $37.3 \%$ of the professionals answered correctly on this matter. As for methods for preventing caries, although $92.5 \%$ said that they were aware of them, only $17.9 \%$ went to the dentist for preventive treatment. Although the majority $(81.3 \%)$ indicated oral hygiene as a way of preventing caries, observation showed that this practice is not always put into effect in the program's day nursery. Regarding when to start toothbrushing in children, $75.0 \%$ of the teachers and $94.4 \%$ of the health professionals said that they were aware of the need to begin brushing before one year of age, although this reply was given by only $52.5 \%$ of the attendants (chi-square, $p=0.006$ ). In view of these results, it was concluded that attitudes toward oral health were not always coherent with the knowledge that these professionals express.
\end{abstract}

DESCRIPTORS: School health services; Education, dental; Oral health; Oral hygiene; Disabled children.

\begin{abstract}
RESUMO: O objetivo deste estudo foi avaliar conhecimentos e atitudes em saúde bucal dos profissionais de educação e saúde, que atuam em um programa de atenção à criança de 0 a 6 anos de idade, portadora de necessidades especiais, em uma instituição municipal pública do Rio de Janeiro. Por meio de um formulário, foram entrevistados 67 profissionais (professoras, atendentes e profissionais de saúde). Os resultados foram comparados aos hábitos de higiene bucal das crianças, através da observação direta da rotina da creche. Embora 97,0\% tenham afirmado que a saúde bucal pode interferir na saúde geral, somente $37,3 \%$ dos profissionais responderam corretamente a respeito dessa interferência. Quanto aos métodos de prevenção da cárie, 92,5\% afirmaram conhecê-los, contudo somente 17,9\% foram ao dentista para prevenção. A maioria $(81,3 \%)$ indicou a higiene bucal como o modo de prevenir a cárie, porém a observação mostrou que nem sempre esta prática é realizada na creche. Quanto à época do início da escovação dos dentes das crianças, $75,0 \%$ das professoras e $94,4 \%$ dos profissionais de saúde afirmaram conhecer a necessidade de iniciar a escovação antes de um ano de vida, sendo essa resposta observada em somente $52,5 \%$ das atendentes (qui-quadrado, $p=0,006)$. Diante desses resultados, pôde-se concluir que as atitudes em saúde bucal nem sempre foram coerentes com os conhecimentos expressados por esses profissionais.
\end{abstract}

DESCRITORES: Saúde escolar; Educação em Odontologia; Saúde bucal; Higiene bucal; Crianças portadoras de deficiência.

\section{INTRODUCTION}

At present, dentistry is mainly concentrated on education. Prevention is the most acceptable way of ensuring oral health ${ }^{22}$, particularly in the case of disabled patients, because these individuals require multiple care due to their systemic condition ${ }^{15}$. One factor also to be considered is the anxiety of parents regarding problems associated with the incapacity of such children, which often delays dental treatment until a significant progression of oral disease occurs ${ }^{22}$. Although they may occur in individuals without systemic disorders, dental caries, gingivitis and lesions in the oral mucosa are more frequent in patients that have some systemic disease $\mathrm{e}^{5,6,7,9,10,19,21,23}$.

$\dagger$ Part of dissertation for the obtainment of Master's Degree.

${ }^{*}$ MSc, School of Dentistry; **Full Professor of Pediatric Dentistry; ${ }^{* * * A s s o c i a t e ~ P r o f e s s o r, ~ C e n t e r ~ f o r ~ S t u d i e s ~ i n ~ P u b l i c ~ H e a l t h ~-~ F e-~}$ deral University of Rio de Janeiro. 
Pomarico L, Souza IPR de, Tura LFR. Oral health profile of education and health professionals attending handicapped children. Pesqui Odontol Bras 2003;17(1):11-6.

Within the context of education and health, the school, in addition to the family, plays an important role in the individual's development, because many children spend a large part of the day at school and this is an environment where they develop important health and behavioral habits. Mallmann $^{11}$ (2001) reported that school is a very rich source of stimuli and it is able to constantly influence children at a stage when they are developing fast. In a study made by Pomarico et al. ${ }^{12}$ (2000), those mainly responsible for oral health education, according to $1^{\text {st }}$ to $4^{\text {th }}$ grade teachers, are the family, teachers and health professionals. For Yoder ${ }^{24}$ (2001), schools should have a dentist or dental hygienist to organize school oral health policy, since most schools have health policies, but few specifically detail oral health. With this in mind, the purpose of this study was to evaluate knowledge and attitudes toward oral health of education professionals and health professionals who work in a program caring for handicapped children, and to compare the results with the observation of oral hygiene habits of the children that use the day nursery of the same institution.

\section{MATERIALS AND METHODS}

All the education professionals (teachers and attendants) and health professionals of a public municipal institution in Rio de Janeiro took part in the study. One of the principal activities of the institution is the Program for Attending Children (PAC) of low socioeconomic level, from 0 to 6 years, which has a day nursery and an encouragement project. The day nursery is attended by 312 children from 0 to 4 years, 40 of which are disabled. The children stay at the nursery all day and are provided with four meals per day. In the encouragement project, the health professionals take sessions with small groups of disabled children from 0 to 6 years once or twice a week. This institution supports low income families which do not have access to private services.

Sixty-seven professionals were interviewed and answered a printed questionnaire containing 16 questions (10 open and 6 closed) on oral health. From that total, 8 people were from Group G1 (teachers), 40 from Group G2 (attendants) and 19 from Group G3 (health professionals: 1 music therapist, 2 psychologists, 1 psychopedagogue, 6 speech therapists, 3 physiotherapists, 2 rehabilitation agents and 4 body therapists). Only one professional from G3 was male. The replies to the teachers' and at- tendants' questionnaires were compared to the routine oral hygiene activities of the children in the day nursery, by direct observation, twice a week, during two months, and data were noted in a field textbook. The answers were coded and inserted in a data bank in the EpiInfo 6.04d program, using the chi-square statistical test with a significance level of $5 \%$ and the weighted kappa test. A qualitative analysis of the direct observation was also carried out. This study was submitted to and approved by the Ethics Committee of the Center for Studies in Public Health of the Federal University of Rio de Janeiro (NESC - UFRJ).

\section{RESULTS AND DISCUSSION}

In the first part of the interview, the professionals were questioned on their knowledge of oral health. Almost all of them (97.0\%) replied that oral health could play a part in general health. However, when questioned on how oral health plays this part, only $27.1 \%$ of the education professionals (G1 and G2) answered correctly (Table 1). The rates were $37.5 \%$ for G1 and $25.0 \%$ for G2. These values were statistically significant (chi-square, $\mathrm{p}=0.012)$. For the American Academy of Pediatric Dentistry $^{2}$ (1996), health programs for the disabled child usually are managed by doctors, mainly pediatricians, who have early access to such patients and can influence their health habits. It is therefore important that these individuals know about oral health.

Little is known about the knowledge and attitudes concerning oral care of other health professionals who, like those interviewed in this study, also have early contact with these children for long periods of time. It was found that the great majority of the professionals, principally those from groups

TABLE 1 - Relationship between oral health and general health, according to groups of professionals. Rio de Janeiro, RJ, 2001.

\begin{tabular}{l|c|r|r|r|r|r}
\hline \hline \multirow{2}{*}{$\begin{array}{c}\text { Oral health } \\
\text { versus general } \\
\begin{array}{c}\text { health } \\
\text { relationship }\end{array}\end{array}$} & \multicolumn{2}{|c|}{$\mathrm{G} 1+\mathrm{G} 2$} & \multicolumn{2}{c|}{$\mathrm{G} 3$} & \multicolumn{2}{c}{ Total } \\
\cline { 2 - 7 } & 13 & 27.1 & 12 & 63.1 & 25 & 37.3 \\
\hline Right & 17 & 35.4 & 6 & 31.6 & 23 & 34.3 \\
\hline Wrong & 18 & 37.5 & 1 & 5.3 & 19 & 28.4 \\
\hline Don't know & 48 & 100.0 & 19 & 100.0 & 67 & 100.0 \\
\hline Total &
\end{tabular}

Chi-square test: $\mathrm{p}$-value $=0.007$ (highly significant). 
Pomarico L, Souza IPR de, Tura LFR. Oral health profile of education and health professionals attending handicapped children. Pesqui Odontol Bras 2003;17(1):11-6.

G1 and G2, that have more contact with the children, were not aware of the real importance of oral health, which is certainly reflected in the routine attitudes of professionals in the day nursery observed in this study.

As for methods for preventing caries, 92.5\% ( $n=62$ ) of the total sample said they knew about them. When asked to specify the methods, high rates of accuracy were observed in the three groups (Table 2). Similar results were seen in the methods used by health professionals that attend hospitalized children in the study of Costa et al. ${ }^{4}$ (2000), where a considerable number of professionals take some action to prevent caries, with oral hygiene being the method most used.

There was a statistically significant difference between G1,G3 and G2 (chi-square, p = 0.006) regarding when toothbrushing begins in children. It was noticed that G1 and G3 mostly said that they were aware of the need to begin toothbrushing be-

TABLE 2 - Caries prevention methods, according to groups of professionals. Rio de Janeiro, RJ, 2001.

\begin{tabular}{l|c|c|c|c|c|c|c|c}
\hline \hline $\begin{array}{l}\text { Prevention } \\
\text { method }\end{array}$ & \multicolumn{2}{|c|}{$\mathrm{G} 1$} & \multicolumn{2}{c|}{$\mathrm{G} 2$} & \multicolumn{2}{c|}{$\mathrm{G} 3$} & \multicolumn{2}{c}{ Total } \\
\cline { 2 - 9 } & $\mathrm{n}$ & $\%$ & $\mathrm{n}$ & $\%$ & $\mathrm{n}$ & $\%$ & $\mathrm{n}$ & $\%$ \\
\hline $\begin{array}{l}\text { Oral } \\
\text { hygiene }\end{array}$ & 2 & 25.0 & 15 & 42.9 & 5 & 26.3 & 22 & 35.5 \\
\hline $\begin{array}{l}\text { Oral } \\
\text { hygiene } \\
\text { other* }\end{array}$ & 5 & 62.5 & 12 & 34.2 & 13 & 68.4 & 30 & 48.4 \\
\hline Other* & 1 & 12.5 & 8 & 22.9 & 1 & 5.3 & 10 & 16.1 \\
\hline Total & 8 & 100.0 & 35 & 100.0 & 19 & 100.0 & 62 & 100.0 \\
\hline \hline
\end{tabular}

*Other methods: diet, visit to dentist, topical application of fluoride. Note: 5 interviewees (G2) did not know how to answer.

TABLE 3 - Opinion on age for starting toothbrushing in children, according to groups of professionals. Rio de Janeiro, RJ, 2001.

\begin{tabular}{|c|c|c|c|c|c|c|c|c|}
\hline \multirow{2}{*}{$\begin{array}{c}\text { Age for } \\
\text { starting } \\
\text { toothbrushing }\end{array}$} & \multicolumn{2}{|c|}{ G1 } & \multicolumn{2}{|c|}{$\mathrm{G} 2$} & \multicolumn{2}{|c|}{ G3 } & \multicolumn{2}{|c|}{ Total } \\
\hline & $\mathrm{n}$ & $\%$ & $\mathrm{n}$ & $\%$ & $\mathrm{n}$ & $\%$ & $\mathrm{n}$ & $\%$ \\
\hline 0 to 11 months & 6 & 75.0 & 21 & 52.5 & 17 & 94.4 & 44 & 66.7 \\
\hline $\begin{array}{l}\text { As from } 12 \\
\text { months }\end{array}$ & 2 & 25.0 & 19 & 47.5 & 1 & 5.6 & 22 & 33.3 \\
\hline Total & 8 & 100.0 & 40 & 100.0 & 18 & 100.0 & 66 & 100.0 \\
\hline
\end{tabular}

Note: 1 interviewee (G3) did not know how to answer. Chi-square test: $\mathrm{p}$-value $=0.006$ (highly significant). fore 12 months of age, whereas in G2, this percentage was observed in half the sample (Table 3).

In respect to attitudes toward oral health, when the professionals were questioned about when they last visited the dentist, $46.3 \%$ answered in the last year. This reply represents $50.0 \%, 35.0 \%$ and $68.4 \%$, respectively, in groups G1, G2 and G3. Therefore, only $12(17.9 \%)$ went to the dentist for preventive treatment, of which 10 were from G3 and none from G2 (Table 4). Considering the replies per group, it could be seen that socioeconomic and cultural factors may have influenced the results, particularly in the group of attendants. This hypothesis is supported by the fact that the attendants were qualified with just elementary school scholarship and were of low socioeconomic level; in addition, some were mothers of children attending the institution, a fact verified through direct observation. It could also be postulated that another group of health professionals not investigated in this study - the pediatricians - also do not prioritize preventive dental visits themselves, since it has been reported that only $21.0 \%{ }^{17}$ and $54.5 \%{ }^{14}$ of them sent their patients to the dentist for preventive reasons.

When questioned about the occurrence of gingival bleeding during brushing, 34.3\% of the professionals answered affirmatively, whilst $69.6 \%$ continued brushing on the bleeding site. Table 5 shows the distribution by groups regarding attitudes toward finding gingival bleeding during brushing. Part of the sample that reported bleeding also adopted the wrong conduct of stopping brushing at this sign of disease $(30.4 \%)$, probably due to lack of knowledge. This result is more worrying as it is noted that these professionals were in G1 $(75.0 \%)$ and G2 $(23.5 \%)$, exactly the ones responsi-

TABLE 4 - Appointment reason according to groups of professionals. Rio de Janeiro, RJ, 2001.

\begin{tabular}{l|c|r|r|r|r|r|r|r}
\hline \hline \multirow{2}{*}{$\begin{array}{c}\text { Appointment } \\
\text { reason }\end{array}$} & \multicolumn{2}{|c|}{$\mathrm{G} 1$} & \multicolumn{2}{c|}{$\mathrm{G} 2$} & \multicolumn{2}{c|}{$\mathrm{G} 3$} & \multicolumn{2}{c}{ Total } \\
\cline { 2 - 9 } & $\mathrm{n}$ & \multicolumn{1}{c|}{$\%$} & \multicolumn{1}{c|}{$\mathrm{n}$} & \multicolumn{1}{c|}{$\%$} & $\mathrm{n}$ & $\%$ & $\mathrm{n}$ & $\%$ \\
\hline Prevention & 2 & 25.0 & 0 & 0.0 & 10 & 52.6 & 12 & 17.9 \\
\hline Caries & 4 & 50.0 & 16 & 40.0 & 3 & 15.8 & 23 & 34.3 \\
\hline Pain & 0 & 0.0 & 17 & 42.5 & 0 & 0.0 & 17 & 25.4 \\
\hline Others* & 2 & 25.0 & 7 & 17.5 & 6 & 31.6 & 15 & 22.4 \\
\hline Total & 8 & 100.0 & 40 & 100.0 & 19 & 100.0 & 67 & 100.0 \\
\hline \hline
\end{tabular}

*Other reasons: calculus, prosthesis, trauma, calculus + prosthesis. 
Pomarico L, Souza IPR de, Tura LFR. Oral health profile of education and health professionals attending handicapped children. Pesqui Odontol Bras 2003;17(1):11-6.

TABLE 5 - Attitude during toothbrushing when gingival bleeding is noticed, according to groups of professional. Rio de Janeiro, RJ, 2001.

\begin{tabular}{l|c|c|c|c|c|c|c|c}
\hline \hline \multirow{2}{*}{ Attitude } & \multicolumn{2}{|c|}{$\mathrm{G} 1$} & \multicolumn{2}{c|}{$\mathrm{G} 2$} & \multicolumn{2}{c|}{$\mathrm{G} 3$} & \multicolumn{2}{c}{ Total } \\
\cline { 2 - 9 } & $\mathrm{n}$ & $\%$ & $\mathrm{n}$ & $\%$ & $\mathrm{n}$ & $\%$ & $\mathrm{n}$ & $\%$ \\
\hline $\begin{array}{l}\text { Continue } \\
\text { brushing }\end{array}$ & 1 & 25.0 & 13 & 76.5 & 2 & 100.0 & 16 & 69.6 \\
\hline $\begin{array}{l}\text { Stop } \\
\text { brushing }\end{array}$ & 3 & 75.0 & 4 & 23.5 & 0 & 0.0 & 7 & 30.4 \\
\hline Total & 4 & 100.0 & 17 & 100.0 & 2 & 100.0 & 23 & 100.0 \\
\hline \hline
\end{tabular}

ble for the supervision of brushing in the day nursery. Even more worrying results were noted in the study of Barcelos $^{3}$ (2000), who found that $55.5 \%$ of those responsible for brushing who reported bleeding stopped their brushing. Conversely, Franco et $a .^{7}$ (1996) verified that parents of cardiac children demonstrated a good knowledge about the benefits of toothbrushing in gingival health.

From the total sample, $76.1 \%$ had children and $60.8 \%$ began brushing the teeth of those children before 12 months of age. This percentage was $50.0 \%$ in $\mathrm{G} 1,50.0 \%$ in $\mathrm{G} 2$ and $92.3 \%$ in G3. When comparing knowledge and attitude regarding the time for starting brushing of the children's teeth, there is coherence in G2 and G3, since $52.5 \%$ of the attendants stated that brushing should begin in the first year, and 50.0\% reported that they had begun brushing their children's teeth at that time. In the case of the health professionals, the percentages were $94.4 \%$ and $92.3 \%$, respectively. Regarding the teachers, percentages were $75.0 \%$ and $50.0 \%$, respectively. Table 6 shows the concordance between theory and practice regarding the age at which toothbrushing of the sample's children should be initiated.

The attendants' knowledge and attitudes, although coherent, may once again justify the actions observed in the day nursery. Although G1 and G3 demonstrated a significant difference in knowledge compared with G2, that knowledge was not put into action by part of $\mathrm{G} 1$, possibly contributing to the attitudes already mentioned in the day nursery. In another segment of the group of health professionals, the pediatricians, the obtained results were similar to those reported by Ribeiro et al. ${ }^{14}$ (1999), where $94.1 \%$ of the doctors recommended toothbrushing before 12 months.
TABLE 6 - Concordance (\%) between theory and practice on age for starting toothbrushing.

\begin{tabular}{l|c|c|c|c}
\hline \hline \multicolumn{5}{c}{ Age for starting brushing } \\
\hline Theory & $\begin{array}{c}0 \text { to } 5 \\
\text { months }\end{array}$ & $\begin{array}{c}6 \text { to } 11 \\
\text { months }\end{array}$ & $\begin{array}{c}12 \text { to } 24 \\
\text { months }\end{array}$ & $\begin{array}{c}\text { Over 24 } \\
\text { months }\end{array}$ \\
\hline 0 to 5 months & 64.3 & 14.3 & 21.4 & 0.0 \\
\hline 6 to 11 months & 5.3 & 78.9 & 15.8 & 0.0 \\
\hline 12 to 24 months & 6.7 & 20.0 & 66.7 & 6.7 \\
\hline Over 24 months & 0.0 & 0.0 & 66.7 & 33.3 \\
\hline \hline
\end{tabular}

Weighted kappa test: $\mathrm{k}=0.580$ (moderate concordance).

When asked about who brushed the teeth of their children when infants, $60.0 \%$ answered that they did it themselves, that is, the guardians, with percentages of $50.0 \%, 69.7 \%$ and $38.5 \%$ respectively in groups G1, G2 and G3. Silveira ${ }^{18}(1996)$ studied undernourished children aged from 36 to 60 months, enrolled in public day nurseries in Teresópolis, and found that in spite of their age, 100\% of the children were responsible for daytime brushing and, in $85 \%$ of the cases, the children were responsible for night-time brushing. Better results were found in this study, where in $60 \%$ of the sample it was the mother who brushed, although it must be stressed that the group with the worst performance was that of the health professionals. If we consider that in the case of very young children with only one adult brushing there could be good quality oral hygiene, it would be expected that all of them brushed their children's teeth at least at night. It should not be forgotten that the professionals emphasized hygiene as the method for preventing caries. In a report by Tomita, Fagote ${ }^{20}$ (1999) involving 52 handicapped children, it was found that only $40 \%$ brushed unaided while $40 \%$ were helped by their guardians, and $20 \%$ by teachers. It was also found that $24.4 \%$ of the children who brushed alone learned from their teachers. This fact is supported by Sarl1 ${ }^{16}$ (1996), who emphasizes that children should have help from their parents and professionals with their hygiene. For Weddell et al. ${ }^{22}$ (2001), parents must establish good oral health habits at home since childhood.

The schedule of activities of the day nursery included toothbrushing after lunch. Observation of the routine during all the period showed that brushing was not always performed and that in the three divisions of children from 0 to 2 years, no type of hygiene was carried out. Although the sam- 
Pomarico L, Souza IPR de, Tura LFR. Oral health profile of education and health professionals attending handicapped children. Pesqui Odontol Bras 2003;17(1):11-6.

ple acknowledges the need for oral hygiene, this was not performed effectively at the day nursery, because although the children stayed there all day, receiving four meals, including supper, brushing was carried out only after lunch, if at all. The teachers and notably the attendants, who were the professionals that stayed longest with the children, when questioned on the matter, blamed this on their troubles and work overload when one of the attendants did not turn up. However, even in such cases, a bath was always given. This conduct can be attributed to the minor importance put on oral health due to insufficient knowledge on the subject. This minor importance can also be detected in attitudes during recreational activities, such as in painting classes at the day nursery, when the education professionals drew the entire human body and the mouth with no teeth. In a study by Pomarico et al. ${ }^{12}(2000)$ with $1^{\text {st }}$ to $4^{\text {th }}$ grade teachers, it was noticed that $62.7 \%$ of teachers instruct their pupils in relation to toothbrushing.

In view of these results, it can be seen that attitudes toward oral health are not entirely coherent with the knowledge that those professionals express. This fact does not agree with the studies of Gama et al. ${ }^{8}$ (1996) and Ribeiro et al. ${ }^{13}$ (1996), which show a low level of knowledge of oral health respectively by educators of municipal day nurseries and teachers. Almeida et al. ${ }^{1}$ (1999), after examining the replies of teachers from the first segment of basic education, regarding the occurrence of dental caries in schools, commented that this

\section{REFERENCES}

1. Almeida PA, Senna MA, Trino MT, Gouvêa MV, Oliveira, GS. Doença cárie - percepção de professores do ensino fundamental na região dos Lagos, RJ. In: $16^{\mathrm{a}}$ Reunião Anual da Sociedade Brasileira de Pesquisa Odontológica: 1999; São Paulo. Anais.

2. American Academy of Pediatric Dentistry. Pediatr Dent 1996;18:1.

3. Barcelos R. Doença periodontal na infância e adolescência. [Monografia de Especialização] Rio de Janeiro: Universidade Federal do Rio de Janeiro; 2000.

4. Costa EMMB, Castro G, Ramos ME, Chianca T, Souza IPR. Projeto odontologia médica: conhecimentos e práticas de saúde bucal para crianças hospitalizadas. Revista do Centro de Estudos - FO/UERJ. 2000;VI:59-63.

5. Dens F, Boute P, Otten J, Vinckier F, Declerck D. Dental caries, gingival health, and oral hygiene of long term survivors of paediatric malignant diseases. Arch Dis Child 1995;72:129-32. population is aware of the seriousness of the disease, although they think it is declining. They also say that there is a great need for investing funds in this sector and for access to health services. This information agrees with Yoder $^{24}$ (2001), who suggests measures for introducing a school oral health program, including oral examinations in preschool children for an early initiation of dental treatment, periodical dental examinations, educating parents and children with emphasis on prevention, encouraging daily brushing, particularly for children with development problems, providing teachers and assistants with appropriate training, discouraging the sale of sweets and candies, and promoting programs for surveying the oral health situation, conducted by voluntary local dentists or hygienists.

If success is to be achieved in these programs, and attitudes changed, then certainly the three components responsible for child education and health, i.e., family, school and health professionals, must take joint action.

\section{CONCLUSION}

This study showed that the knowledge of oral health by education and health professionals was not entirely satisfactory and that attitudes were not always coherent with the expressed knowledge.

\section{ACKNOWLEDGMENTS}

To Mônica Magnanini (Statistician at NESCUFRJ) and to the board and professionals of the institution participating in this study.

6. Donatsky O, Ahlgren P, Hansen PF. Oral health status and treatment needs in long-term medicine patients in a Copenhagen hospital department. Community Dent Oral Epidemiol 1980;8:103-9.

7. Franco E, Saunders CP, Roberts GJ, Suwanprasit A. Dental disease, caries related microflora and salivary IgA of children with severe congenital cardiac disease: an epidemiological and oral microbial survey. Pediatric Dent 1996;18:228-35.

8. Gama R, Abreu FV, Primo LG, Souza IP. Avaliação da educação sobre saúde oral em creches municipais. ROE 1996;3:145-7.

9. Hede B. Oral health in Danish hospitalized psychiatric patients. Community Dent Oral Epidemiol 1995;23:44-8.

10. Madigan A, Murray PA, Houpt M, Catalanotto F, Feuerman M. Caries experience and cariogenic markers in HIV-positive children and their siblings. Pediatric Dent 1996;18:129-36. 
Pomarico L, Souza IPR de, Tura LFR. Oral health profile of education and health professionals attending handicapped children. Pesqui Odontol Bras 2003;17(1):11-6.

11. Mallmann LP. Algumas reflexões sobre a prática da fonoaudiologia na escola como triagem fonoaudiológica: relato de experiência. J Bras Fonoaudiol 2001;2:55-8.

12. Pomarico L, Ramos AR, Souza IPR, Tura LFR, Magnanini MMF. Higiene bucal no ambiente escolar - avaliação de professoras. J Bras Odontoped Odonto Bebe 2000;3:295-9.

13. Ribeiro LP, Almeida FK, Vieira AR, Primo LSSG. Conhecimentos e práticas de higiene bucal em crianças e professoras. In: $13^{a}$ Reunião Anual da Sociedade Brasileira de Pesquisa Odontológica: 1996; São Paulo. Anais.

14. Ribeiro LP, Modesto A, Souza IPR. Conhecimentos e atitudes de alguns pediatras da cidade do Rio de Janeiro sobre aspectos de saúde oral do bebê. J Bras Odontoped Odonto Bebe 1999;2:345-50.

15. Roberts IF, Roberts GJ. Relation between medicines sweetened with sucrose and dental caries. Br Med J 1979;2:14-6.

16. Sarll DW. Who is responsible for good oral health? Br Dent J 1996;80:164-7.

17. Schalka MMS, Rodrigues CRMD. O perfil do médico pediatra da cidade de São Paulo em função de seu conhecimento em promoção de saúde bucal. J Bras Odontoped Odonto Bebe 2000;3:62-71.
18. Silveira RG. Cárie em crianças desnutridas: estudo comparativo de prevalência. [Tese de Mestrado] Rio de Janeiro: Universidade Federal do Rio de Janeiro; 1996.

19. Souza IPR, Teles GS, Castro GF, Primo LG, Vianna RBC, Peres M. Prevalência de cárie em crianças infectadas pelo HIV. Rev Bras Odontol 1996;53:49-51.

20. Tomita NE, Fagote BF. Programa educativo em saúde bucal para pacientes especiais. Odontologia e Sociedade 1999; 1:45-50.

21. Wahlin YB, Matsson L. Oral mucosal lesions in patients with acute leukemia and related disorders during cytotoxic therapy. Scand J Dent Res 1988;96:128-36.

22. Weddell JA, Sanders BJ, Jones JE. Problemas dentários da criança deficiente. In: McDonald RE, Avery DR. Odontopediatria. Rio de Janeiro: Guanabara Koogan; 2001. p.413-35.

23. Willershausen B, Lenzner K, Hagedorn B, Ernst CP. Oral health status of hospitalized children with cancer: a comparative study. Eur J Med Res 1998;3:480-4.

24. Yoder KM. Saúde bucal da comunidade. In: McDonald RE, Avery DR. Odontopediatria. Rio de Janeiro: Guanabara Koogan; 2001. p.583-94.

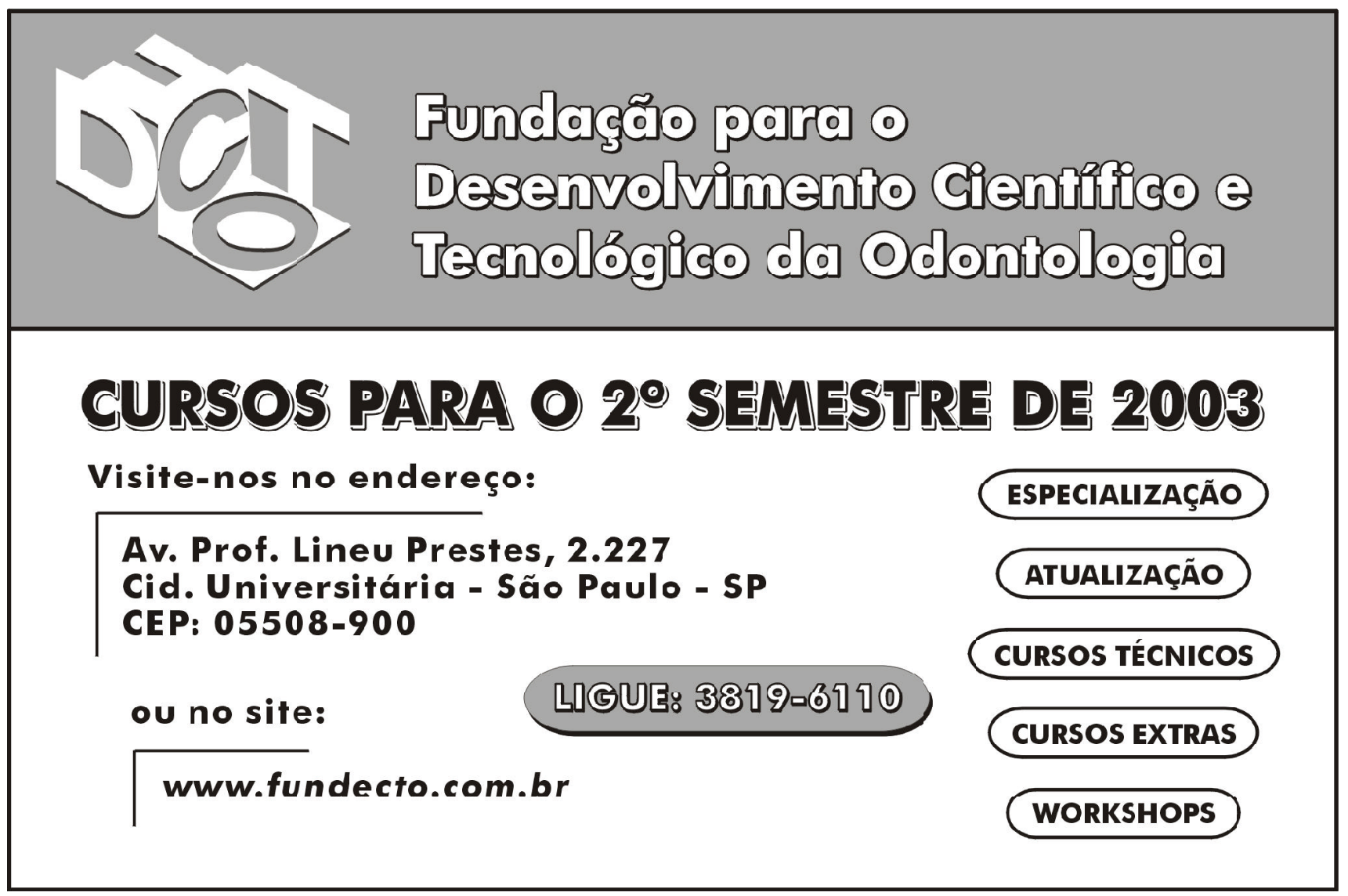

